\title{
THE ENIGMA OF GÜLCHATAI'S FACE OR THE FACE OF THE OTHER
}

\author{
Serguey N. Yakushenkov (a)
}

(a) Astrakhan State University. Astrakhan, Russia. Email: shuilong[at]mail.ru

\begin{abstract}
The article analyzes the problem of interpretation of the image of the Other through their Body. In modern society, the problem of denoting the Other is extremely important. Very often mass media resorts to the metonymy of the body for naming the Other, for example, "the face of Caucasian nationality". This usage of the word 'face' as a certain metaphor to describe the nationality depersonalize people. The usage of the metonymic method of pars pro toto indicates archaic nature of the notions related to the corporality of the Other. As an argument, the author quotes numerous examples of images of mythological heroes whose otherness is expressed through hypertrophied bodily parts, for instance a large face or a tremendous head. The article analyses the popular Soviet movie "The White Sun of the Desert", because this movie demonstrates in the best way the Soviet and post-Soviet pattern of Cultural Encounter. The astonishing popularity of the movie in the USSR shows that the representation of a face-to-face meeting with the Other that the movie offered was very close to the Soviet viewer. The author argues that Russian society still faces the challenge of rediscovering the dialogue of cultures instead of a monologue.
\end{abstract}

\section{Keywords}

the Other; face; body; movie "White Sun of the Desert"; image; Gülchatai; Cultural Encounter

This work is licensed under a Creative Commons «Attribution» 4.0 International License. 


\section{ЗАГАДКА ГЮЛЬЧАТАЙ ИЛИ ЛИЦО ДРУГОГО}

Якушенков Сергей Николаевич (a)

(а) ФГБОУ ВО "Астраханский государственный университет". Астрахань, Россия.

Email: shuilong[at]mail.ru

\section{Аннотация}

В статье анализируется проблема интерпретации образа Чужого через его телесность. В современном обществе как нельзя остро стоит проблема обозначения Чужого. Очень часто СМИ прибегают к телесной метонимии, например, «лицо кавказской национальности». Используя слово «лицо» как некую метафору для обозначения его национальности, они тем самым обезличивают его. Кроме этого употребление такого метонимического приема pars pro toto приводит нас к архаичности этих представлений, связанных с телесностью Другого. В качестве аргумента автор приводит многочисленные примеры образов мифологических героев, инаковость которых выражена через отдельные гипертрофированные части, а именно - большое лицо (голова). Основной акцент в статье сделан на анализе культового советского фильма «Белое солнце пустыни», так как по мнению автора этот фильм наилучшим образом демонстрирует советскую, да и постсоветскую культурную парадигма, описывающую модель встречи с Другим. Огромная популярность фильма показывает, что эта модель встречи с Чужим оказалась понятна и близка советскому зрителю.

По мнению авторов, и до сих пор перед российским обществом стоит важная задача по-новому осознать значимость диалога культур, исключив монологичность.

\section{Ключевые слова}

Другой; Чужой; лицо; тело; образ; «Белое солнце пустыни»; Гюльчатай; встреча цивилизаций 


\section{INTRODUCTION: THE OTHER WITH A HUMANE FACE}

From childhood, we learn that the Other is a one who has a different body, not like ours, his body is strange to us. His (her) bodily otherness turns into a marker, allowing us to identify the Other or the Alien. Regular cultural patterns through a variety of means teach us to navigate in the "alien" bodies, to find friends and strangers among them. Both official propaganda and popular culture (which is not one step behind the propaganda) are at work here, imposing the images of an Alien on us.

Tales and myths play a huge role in understanding physicality, it is from them that we first learn how the bodies of the Other or the Alien differ from ours. Fairy-tale characters illustrate that perfectly, it's enough to mention such characters of Russian folklore as Baba Yaga and Koschey the Immortal - the bodies of both are grotesque. Baba Yaga has a bony leg, her huge nose sticks into the ceiling of her hut ${ }^{1}$. In other words, she lacks something (bony leg), but her nose is an excess. Sometimes the description of her image includes some remarks on her buttocks and genitals $^{2}$ (Johns, p. 146). Her other feature is that she can fly through the air in a mortar ruling with a broom.

In the images of fairy-tale characters, we find what distinguishes us from them. The positive heroes are powerful, but their bodies are commensurate with ours, unlike the bodies of the giants, who are fought by the brave tailors, heroes lacking in size but winning in intelligence. The hero who fights on our side is no different from us.

But the children's literature of the Soviet period somehow breaks the paradigm. One of the most favourite characters of this literature is Uncle Stiopa the Giant ${ }^{3}$. The hero is a kind giant or rather a very tall young man. Uncle Stiopa, presented in the poem as if seen from some distance, always comes to the rescue, especially to kids, he is a model of good behavior. He dreams to be a sailor, and after his service in the Navy he becomes a policeman ${ }^{4}$. He prefers to remain in the shadows, shy of his appearance. In the case of the fairy-tale giant, we observe a different situation - their enormous size is supported by their excessive vanity, arrogance of their strength.

1 Her enormous nose is quite functional though. She can smell the hero without seeing him ("foowhoo! It smells of the Russian scent!")

2 This description of buttocks and genitalia («wiry buttocks, soaped vagina»), considering the old age of the witch is not erotic and serves to underline her grotesqueness. But Baba Yaga is not always deprived of fertility, there are fairy-tales in which small kids suck at her giant breasts (Johns, p. 158). Such texts though are more exception than the rule. Sometimes Baba Yaga steals other people's children (like in a fairy-tale «Geese-Swans»)

3 Uncle Stiopa - is a hero of children poems by Sergey Mikhalkov. The image first appeared in 1935.

4 He becomes a policeman in a poem published in 1954. 
In traditional culture, a positive hero often has miniature physicality - just remember Cinderella, who has the smallest foot in the kingdom. With all her positive qualities, Cinderella is a typical character with the features of the Other. She is an orphan, forced to serve her half-sisters and her stepmother. Cinderella looks dirty (that's why she is called Cinderella (Italian Cenerentola; French Cendrillon; German Aschenputtel, i.e. covered with ashes), but her soul is clean. There is a whole set of such miniature characters in fairy-tales, it's enough to mention Tom Thumb and his female counterpart Thumbelina, etc.

The appearance of the negative character is always grotesque. There is no harmony in it; it is most often asymmetric or destructive. The destructive appearance of the Other destroys the familiar image, and a meeting with him "face to face" does not bode well for us, since it hints at the otherness and possibility that the being may be from 'another world'.

But the destructive Other can be from this world. Here too the meeting with them, according to many, does not bode well, since the Other in this case is a kind of marginal creature (social, mental, ethnic, etc.). That is exactly what F. Nietzsche wrote about in his famous work "Thus Spoke Zarathustra" In the second part, in the chapter "On the Atonement", F. Nietzsche describes the meeting of Zarathustra with cripples: «I see and have seen worse, and some of it so hideous that I do not want to speak of everything, and of a few things I do not even want to remain silent; namely human beings who were missing everything except the one thing they have too much of - human beings who are nothing more than one big eye, or one big maw or one big belly or some other big thing - inverse cripples I call such types» (Nietzsche, p. 109).

The Other does not accidentally appear in the story, they suddenly turn out to be a symbolic figure: not a separate personality, but a certain combination of personalities. The appearance of cripples on the path of Zarathustra is just a metaphor, which is why he calls them "inverse cripples". For Nietzsche, such a person is just a radical Other who is missing everything except "one thing" that they have "too much of"

Society does its best to teach us from childhood to recognize the Other. Soviet and then post-Soviet society is no exception. The Soviet state created a "new historical community" - the Soviet people, based on Russian culture and mainly the Russian ethnic group. Ignoring other cultures and other ethnic groups led to the fact that the most diverse ethnic groups began to fall into the list of Others. The main "watershed"

1 That's why Derrida calls his analysis of Nietzsche "Otobiography", i.e. a biography of the ear, hinting at the symbolic redundancy of one organ in the Other - this is the "Ear of the Other", which for him is a starting point for the discussion of Nietzsche (Derrida, 1985). 
in the Russian Empire occurred mainly along the lines of Orthodoxy / other religions. By cancelling the religious marker, Soviet propaganda thereby increased the number of subjects falling under the concept of Other. At the same time, it should be recognized that official ideology not only did not encourage xenophobia, but also struggled with it in many ways ${ }^{1}$.

The simplicity of intercultural relations, reflected in propaganda films such as "They Met in Moscow" (Svinarka i pastukh, Engish: "The Swine-herd and the Shepherd", 1941), gave a distorted view of the Other. The main idea of these films, was reflected in the main song of the film.

\author{
"And whichever way I go, \\ Whatever grass I walk on, \\ I'll never forget a friend, \\ If I met them in Moscow" (Khrennikov, p. 46).
}

Moscow was presented as a meeting place uniting people of different nationalities ${ }^{2}$.

The Soviet state tried to acquaint Soviet people with national cultures and to propagate the Soviet way of life in the national outskirts ${ }^{3}$, however, the amount of this information was significantly small. The Russian population of the USSR was more than $50 \%$, but they poorly knew how the national suburbs lived.

Strange as it may seem, some breakthrough was already made during the years of World War II". The already mentioned "The Swine-herd and

1 The collapse of the Soviet Union generated a wave of nationalism among almost all ethnic groups.

2 According to the plot of the movie, a Russian swine-herd Glasha fell in love with a shepherd from Dagestan.

3 It should be accepted that in general, the Soviet government did a lot for the development of national suburbs. Moscow contributed to the formation of national intelligentsia, the development of national literature, the reform of the written language, the elimination of illiteracy, etc.. However, many of these measures were haphazard and sometimes anecdotal, such as the reform of the written language among the peoples who practiced Islam and traditionally used the Arabic alphabet. This movement began in the beginning of the 20s. The first ethnic group to move to the Latin alphabet were Azerbaijanis (1921-22). This process lasted until the beginning of the 30s. In addition to the peoples who used the Arabic alphabet earlier, there were also ethnic groups whose scripts were based on Mongolian script, such as Kalmyks and Buryats. Plans were even made to convert the Russian language to the Latin alphabet. All this was done within the framework of the nativization policy, which implied the development of national cultures, national education, authorities, etc. (Jersild, pp. 155-159). However, in the early 30s there was a dramatic shift in the national policy. Although some ethnic groups were still in the process of switching to the Latin alphabet, there was a general turn towards Russification. And in the area of national writing, the transition to cyrillization. As a result, all this led to a decline in literacy. In some cases, the curiosity of the policy was also in the fact that a number of ethnic groups had already been using the Cyrillic alphabet before they were shifted to Latin script

4 From the very beginning, the Soviet authorities took a variety of steps towards nation-building in the national outskirts. At the same time, this policy was usually faced with a variety of subjective 
the Shepherd" was shot in 1941, in 1943 "Nasreddin in Bukhara" ${ }^{1}$ was shot at the Tashkent film studio, in 1945 the operetta "Arshin Mal Alan" (The Cloth Peddler) was shot, in 1948 "Keto and Kote" and many others. All of them showed the national specifics of ethnic suburbs, and many of them were made at national studios. "Arshin Mal Alan" was shot at the Azerbaijanfilm (Baku Studio), Keto and Kote at Georgian Film Studio (Tbilisi Film Studio). All these films were very popular among Soviet viewers.

In the 50s many other national studios - Uzbekfilm, Tajikfilm and many others also activated. All of them popularized their national culture, especially music and dance. In the late 50s the number of films of national studios has increased even more. At the same time, the plot, and the events of these films dealt with the end of the XIX century. In other words, they were not connected with the present. The operetta "Arshin Mal Alan" was written by an Azerbaijani composer Uzeyir Hajibeyov in 1913. "Keto and Kote" was written even earlier in 1882 by Avksenty Tsagareli - a Georgian playwright ${ }^{2}$.

In the $50-60 \mathrm{~s}$ as the activities of national film studios increased significantly, the Soviet audience was able to peer into the dense curtain of the national outskirts. The musical culture of these peoples, represented by numerous national performers, also played a special role in popularizing oriental culture. True, as was already mentioned, this image of the Soviet East was riveted from a variety of patchwork stripes that did not allow the viewer to see the true "face" of this Other"

factors that negated all its successes. The work of Vostokkino (later renamed to Vostokfilm), created in 1928 , is very illustrative in this context. The goal of the studio was the production of 'truly eastern' films, the promotion of cinematographic culture and cinema networks in the national republics, and the development of local film production and distribution. Vostokfilm declared its commitment to portraying 'the East without embellishment', and produced a large number of kulturfilms on the national minorities in the Soviet Union (Sarkisova, p. 100). Soon the work of the film studio was found to be of poor quality, and a reorganization of the studio (1932) followed, but in 1936 it was disbanded, and many of its employees were repressed. It is noteworthy that many other studios, including Ukrainian ones, were included in Vostokfilm. Practically, Vostokfilm had to deal with almost all films of national republics. In other words, the East is what lies outside the Russian world.

1 In 1946, the Tashkent Film Studio made another film about Nasreddin - "The Adventures of Nasreddin". This activity of the Tashkent Film Studio was connected with the fact that many actors of film studios and theatres moved to Tashkent during the war.

2 The play was originally staged under the title "Khanuma" (1882).

3 The desire to see the face of the bride-to-be is the main motive for the film "Arshin Mal Alan". According to strict rules of wedding etiquette, the groom was not to communicate with his future bride. He usually did not know who she was, as all the issues with the choice of bride were solved by his and her parents. A rich young man does not want to marry the one whom he will be offered. He wants to do so at the heart's command. To solve this problem, he dresses up as a cloth peddler, on the advice of a friend. These sellers were allowed to enter the women's half of the house because their status was not high and they were treated as service personnel. But in this case the main character could see the girl's face and choose to marry her. The film introduced not only the strange 
Not only the protagonist of the film "Arshin Mal Alan" was concerned about the inability to see the face of his bride. The entire USSR, and then post-Soviet Russia, also concentrated around the Face of the Other. This fixation on the face of the Other is simply amazing. Often it is the "face" in post-Soviet Russia who begins to designate the Other, to replace them, to represent them - it suffices to remember the numerous news reports in the media or police reports: "the crime was committed by an unidentified face", "a face of Caucasian nationality ${ }^{1}$ was detained". There were also "positive" examples of using the face metaphor: "and other official faces" (meaning "other officials"), "company face", "important face" (VIP). Here we encounter a complex metonymy (pars pro toto), that is, the designation of the part instead of the whole, the face in this case acts as a metacharacter, designed to indicate the significance of the subject.

As we can see, it is a person who now has a nationality, who commits a crime, who may be important or official, who represents someone, who acts as a symbol of a company or community rather than of the Being. The Face no longer is a part of a body, it does not need it, since the face itself is sufficient, and sometimes even redundant, since, being itself a part, it can be represented through its separate parts: mouth, nose $^{2}$, eye, ear, moustache, beard, hair, etc.

All these parts of the Other can irritate us, make us to laugh or to feel aggression. They can be a symbol of right or wrong, it is against them that we often fight. It is appropriate to recall the annoyance or even aggression of Peter the Great against the beards of his courtiers - the boyars $^{3}$. The desire to deprive them of their beards, that is, their traditional "face", to make them "naked-faced", was the usual mechanism of struggle with the person and their "essence", which of course can't be reduced to either the face or the beard. And yet, it is the beard that can act as a

customs of the national suburbs, but also formed the image of the East - luxurious palaces,

fountains, bright flowers, plenty of fruit, heroes who not only spoke, but also sang constantly. All this created an image that as if descended from the pages of "A Thousand and One Nights".

1 The term 'Caucasian nationality' is used differently in Russia, not in the same meaning as in USA where it has racial connotations. In Russia, it indicates a person from the North Caucasus.

2 Transformation of the organ (a nose) into an important face we find in N. Gogol's novel "The Nose". The St.-Petersburg Collegiate assessor, having woken up, finds out that his nose has disappeared, and in its place, there is a smooth surface. He goes to the police to report the disappearance, but on the way, he meets his nose dressed in the uniform of the State Councilor, which corresponded to his higher status than the Collegiate assessor. The nose makes visits and even prays in church. Without analyzing the semantics of this image, we will only notice that this transformation of the body organ into a character seems to us, although fantastic, nevertheless quite typical of the Russian mentality, fixated on a face. If the face can be official, then why this place can't be reserved for the nose?

3 When Peter the Great came to power, he actively fought against old traditions, including the tradition of wearing beards, which many Russians saw as a symbol of belonging to Orthodoxy. In 1698 , the right to wear a beard was subject to a tax, in some cases very high. Peter the Great even shaved off the beards by himself to several famous boyars, even to prince Romodanovsky. 
symbol of otherness, which indicates the Other. It is enough to recall the famous folk character Blue Beard from the tales of Charles Perrault. We cannot but also mention dwarf Chernomor from Pushkin's poem "Ruslan and Lyudmila" with his huge beard, in which all his magical power was stored. Here we have a true Nietzschean character - "missing everything" and only the beard is "excessive". Depriving him of this part of the body an act insignificant from a physiological point of view - has tragic consequences for him.

We refer again to the understanding of the Other by E. Levinas through the terms of time and existence, since a Person (a being in time) has a certain entity (self, beings), represented through a certain mask or face. Thus, a person is a Being that has a face. Depriving a person of their habitual face is an act close to the murder of this person. Depriving the face of its habitual part (beard, nose, ears, etc.) is an act aimed at killing this person. That is why the illustrious emperor so loved to drag the boyars by their beards or even cut the beards off, depriving boyars of their personality and identity.

It would be a simplification to think that the struggle with the "face" is the specificity of only Peter's times. In the 1960s and even 1970s of the last century, there was an active struggle against the unapproved appearance of the Soviet youth imitating the Beatles group, the police caught them and cut their long hair, depriving them of "Western" identity. True, in the 1980s. the face somewhat lost its significance, and the Other, besides the face, acquired some other features, but in the 1990s. the significance of the face again increased greatly. It was then that "faces of the Caucasian" and "Slavic nationality" appeared. It is noteworthy that people of Jewish nationality or Chukchi, Tajik or Moldavian nationality did not "arise". We dare to assume that the Chukchi, Jew, Moldavian or Tajik, of course, were the Others, but they were not Aliens. The Chukchi, if they were the object of Russian humour, represented by jokes, generally turned out to be as impersonal as possible, that is, "deprived of a face". The jokes constantly featured a certain faceless Chukchi as a collection of persons that have no individuality - no face or a name ${ }^{1}$.

The obsession of the Russian discourse with the Other and the Alien is simply amazing, but easy to explain. Russian mentality as a whole was formed in the frontier, that is, in a constant clash with the Other and even the Alien. From ancient times, East Slavic cultures were formed in the

1 It is noteworthy that the Russian, Germans, French and English became faceless in Russian anecdotes. But the Jew, as a rule, got a name: Abram (Yosia, Moisha, or some others) for a man and Sara for his wife. He even often had a last name - Rabinovich. It is true that not only Jews get names in such anecdotes. Representatives of various Caucasian ethnic groups might also receive them (Maga, Ahmed, etc.). 
border zone, and on the one hand, they were limited by the German world, and on the other - with Finno-Ugric. In the Middle Ages, the Turkic world (Avars, Torques, Cumans, Pechenegs, and many others) joined the fight. Later, this factor of "intermediateness" increased even more with the advent of the Mongols in Russia. The Other's face constantly reminded of itself, sometimes worried, but often scared, forcing to be wary of the Alien.

True, these fears of "losing one's face" were more often far-fetched than real. Being a "border people", Russians actively used the achievements of other cultures, made them their own, absorbing not only things, but also Persons, privatizing them, dissolving them in themselves, becoming Others, but remaining themselves.

This "meeting" with the Other in the history of the Russian state was taking place almost until the middle of the 20th century, when once again it was necessary to do the impossible, to "save one's face" by defeating the bearers of the idea of racial superiority. The fight against Nazism again gave rise to the problem of the Alien, even exacerbated it.

A Nazi has always been looked upon in Russian cultural landscape (films, newspaper drawings) as a subhuman, a bearer of special features, a special face. Their appearance was devoid of humanity, and their faces were unattractive. Therefore, the fight against these sub-humans, nonhumans was natural, regular and fair ${ }^{1}$.

\section{THE HIDDEN FACE OF THE OTHER}

A kind of culmination of the symbolism of the Face of the Other and its importance for Soviet culture was the cult film "The White Sun of the Desert". Without exaggeration, this film became one of the most beloved among the Soviet and then Russian viewers. Many phrases from the film turned into catchphrases, monuments were erected to the characters of the film. It has become a good tradition among Soviet cosmonauts to watch this film before flying into the Space.

Everything in this film is controversial and ambiguous. It could become a kind of guidebook, or better to say guidefilm, explaining many aspects of Russian culture and its relation with the Other. And at the same time, it is one of the most difficult films in the history of Soviet cinema. It was very difficult to shoot, even at the initial stage; the actors were often

1 Only with the release of the popular film "Seventeen Moments of Spring" (1973) the appearance of the Nazi (Alien) changed. In the interpretation of the best actors of Soviet cinema, Nazi Persons appeared before us, their faces were humane in their own way, and the characters were recognizable. They were bright, interesting and sometimes attractive.

2 It was released exactly 50 years ago - March 30, 1970, at the very moment when we are writing this article, which in itself is quite symbolic. 
replaced even in the half-way of the shooting process. It was assumed that the film would be shot by one director (Andrei Konchalovsky), but then, another director (Vladimir Motyl) started shooting it. The film is also poorly defined in terms of genre identity ${ }^{1}$.

The Soviet government was very carefully monitoring the development of national cinema. Most leaders of the USSR loved cinema and took an active part in the work of cinematography (Goskino). As a rule, limited screenings of films were arranged for the state authorities (Razzakov, 2004, p. 340). They saw films before the common viewers could see them.

The opinions of the General Secretary of the Communist Party served very often as a counterweight against the harsh dictatorship of officials from the Goskino and other members of the CPSU Central Committee, who often had a different opinion about many films.

Thus, censorship of the Goskino, and these secret screenings, as well as internal fierce competition among directors, formed Soviet cinema in a special way, creating a kind of collective image of the depicted. As a result of a tough selection, only the movies were released in which all ideological canons were observed, or alternatively those the highest representatives of the Soviet government liked personally. Stalin generally believed that cinema plays a very important role in the political struggle. In his opinion, "a good film is worth several military divisions" (Maryamov 1992, p. 49). The increased interest on the part of the authorities in the cinema ultimately led to the fact that films were shot for the sake of several people or customized to their desires ${ }^{2}$.

These interests played a special role in the fate of a film: the authorities' personal likes or dislikes could ruin or save it. Regarding the "White Sun of the Desert", Brezhnev's positive attitude towards this film completely overshadowed the negative attitude of the Goskino admission committee and thereby saved it.

This attitude to cinematography gave birth to a special phenomenon that American political philosopher Michael Shapiro defined through the prism of intimacy: «Historically, the relationship between cinema and nationhood has been intimate. In most cases, and in many national venues, film has been supportive of state cultural governance - the practice in which state-oriented cinema constructs homogeneous and

1 American researcher Seth Graham defines this film as "an adventure film with comic elements» (Graham, 2016, p. 174), which is hardly appropriate, due to the fact that many positive characters die in the final of the film (Vereshchagin, Petrukha, Gulchatai).

2 It cannot be said that these desires were so extravagant, often they fully coincided with the moods of a significant part of the audience. Due to that, Soviet audience was able to watch such films as "The White Sun of the Desert", "Caucasian Bridenapping”, "Belorussian Station", and many others that the Soviet audience loved so much. 


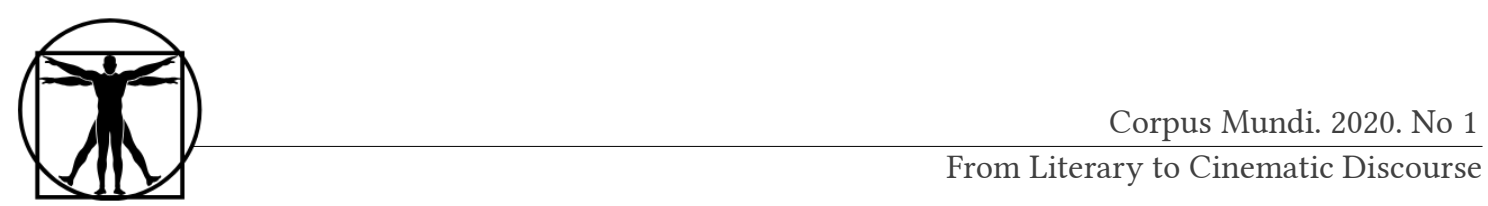

coherent national cultures» (Shapiro, 2013, p. 32). He referred to this phenomenon as «cinematic nationhood». According to him, «cinematic nationhood is the process through which film has been involved in the cultural articulation of the nation-building and sustaining projects of states» (Shapiro, 2004, p. 130), (Shapiro, 2013, p. 32), (Shapiro, 2016, p. 66). He repeats this idea many times in many articles and monographs, as he found it very important in discussion how US national history was reflected in the cinema, especially in relations with Native Americans. In the Soviet Union we had the same situation.

In attempts to construct a new "cinematic nationhood", and especially in relation to the Eastern Other, the Soviet cinema was forced to follow the old pre-revolutionary tropes that were characteristic of almost many national scenarios. Soviet orientalism constantly found itself between the two images of the Soviet East, inherited from the Russian Empire. These two images held it tenaciously, and, perhaps, still continue to hold Russian cinematography to nowadays. One trope described the East as a space of Dystopia, the other as Utopia. The East was often the place where nomads threatened the security of the Russian state, where battles with nomads were considered priority in Russian history ${ }^{1}$.

The Mongolian Golden Horde was a kind of standard of the enemy, a universal symbol of the invader. It is no coincidence that during the Second World War, in the famous patriotic song "Holy War", written immediately after the attack on the USSR, we find the designation of German troops as the Horde:

Arise, the Great Country,
Arise for a final fight
Against the dark fascist power,
Against the damned Horde

Indeed, according to many Russians, the East is a place where lawlessness reigns, human life is worth nothing, where a person is subjected to merciless exploitation. Therefore, the arrival of Russia in Central Asia was perceived as a civilizational mission. The Red Army was deemed to have brought the liberation from violence and the universal peace. The Russians were believed to have freed the peasants, endowed

1 «The general attitude toward nomads was heavily affected by the long tradition of studies on the Golden Horde civilization; Russian historians repeatedly underlined the important role that the Golden Horde had played in Russian history. The Golden Horde had been viewed as a union of barbarian bands with rulers that despotically suppressed settled peoples such as the medieval Christian Russians and the Muslim Volga Bulghars» (Bustanov, p. 39).

2 Vstavay, strana ogromnaya / Vstavay na smertnyy boy!/ S fashistskoy siloy tyomnoyu, / S proklyatoyu ordoy. 
them with land, liberated women, founded schools in which children of the poor could study, etc.

All that found its reflection in Soviet films about Central Asia. They "consistently represented the region and its peoples as backward and exotic others, and served as a culturally constructed mode of group identification. Indeed, despite the Bolsheviks' rhetoric of eliminating ethnic and regional identities in favor of a class based one, the Soviet Union inherited and propagated Russian imperial Orientalism" (Prusin, Zeman 2003, 259).

Not only Dystopia was the hallmark of the East. Utopia was also a typical theme of this topos. We already said that many films on oriental themes were interesting to the audience, as they showed a fabulous paradise with palaces, fountains, beauties, etc. All the attempts to show the East without embellishment, eastern exoticism failed. Speaking of "The Minaret of Death" (1925) - one of the first films shot in Bukhara, the authors of "History of Soviet Cinema. 1917-1967" noted: "Although the eastern legend of the 16th century formed the basis of the "Minaret of Death", it was modelled after Western bourgeois oriental paintings. The pseudo-exotics of Khan's palaces and harems, abductions and chases - all this was infinitely far from the life of the true East" (Abul-Kasymov, Ginsburg, Dolinskiy, Zhurov, \& Zak, p. 701).

At the same time, filmmakers could not avoid showing this eastern exoticism. This is what the viewer liked; it was for these exotics that the viewer went to the cinema. In this regard, the assessment of these films by spectators and critics was radically different. Critics, as a rule, rated such films as "The Legend of the Maiden's Tower" (1924) or "The Minaret of Death" rather low, but the audience voted for them with roubles.

All that created a situation of «imagined society» (Anderson), or even «imagined societies». Each of these films narrated different stories. One of the movies described profound changes in the Soviet East: schools opened, books written, films produced, great numbers of educated young men and women etc. In two others societies were shown like two sides of one imperial coin: on the one side, there were romantic stories of love or old tales of Oriental mystery or wisdom; and another one told about heroic deeds, battles, victories, achievements, and so on.

The Soviet audience wanted to see all these sides, and not just the one that told about the successes of the Soviet regime. There was a strong request as to the heroic side, i.e. the struggle with the forces of evil, and the idealistic (romantic), with its palaces and beauties. The viewer wanted to know the East in all its manifestations ${ }^{1}$, because "the ability to

1 Maybe that's the reason why Indian cinema was so popular among Soviet viewers. 


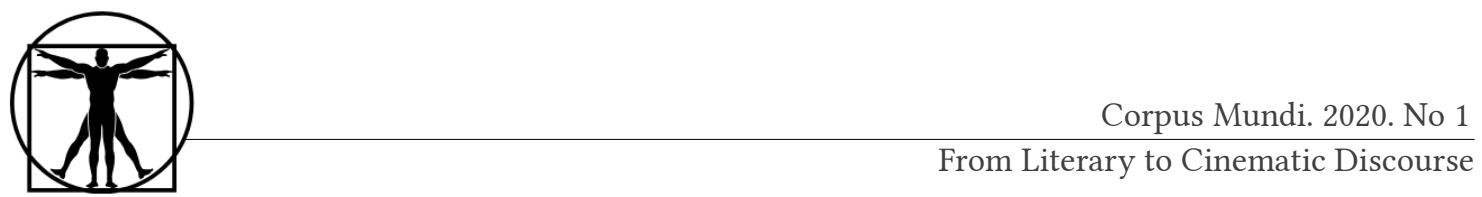

'visualize' a culture or society almost becomes synonymous for understanding it" (Fabian, p. 106).

Everyone needed the visualization of the Other, both the highest authorities of the Soviet Government and ordinary spectators. Everyone had a request for such a film. But within the framework of genre specificity, there was a void in Soviet cinema, which is quite understandable, since Soviet cinema in the 1920s and 1930s. was at the stage of formation, "cinematic nationhood" was only at the stage of construction. Many genres were in conflict with the canon or could not be accepted because of their origin in the West, for instance, a Western.

At the same time, typologically and thematically, the need for films like Westerns was very acute. Western at the deepest level corresponded to the cultural patterns of Soviet, and indeed Russian society. Among the ideas that influenced the cinematic discourse was the idea of the civilization mission of Russian / Soviet society. On the one hand, the CPSU condemned Russia's colonial policy in Central Asia, but on the other, it did little except for this declarative condemnation.

One more thing that radically influenced the development of cinematography, and indeed of the entire Soviet culture, was the gender aspect. Symbolic gender representation was very important for narration about historical events, landscapes, peoples, etc. Of course, such a symbolism can be found among all peoples, however, due to the specifics of the Russian language ${ }^{1}$ these associations acquire additional sounds.

Sometimes this symbolism found a real embodiment, as, for example, in the sculpture symbolizing the union of the working class and the peasantry. The sculpture is a figure of a male worker with a hammer and a female peasant (kolkhoznitsa) with a sickle (V. Mukhina, 1937). Both touch each other with their tool-clenching hands, which symbolized the union of the two classes. Although the sculptures are completely devoid of an erotic connotation ${ }^{2}$, however, on a symbolic level, it seems to be implied. The connection of the female image with fertility is clearly visible in Russian culture (Bonnell, p. 79). Gender symbolism was also reflected in the famous fountain "Friendship of Peoples", in which the Soviet Union republics were represented as female figures.

Therefore, it is not surprising that the gender issue became one of the most important in many orientalist films shot in the USSR. The participation of the Red Army in the liberation of Central Asia from the old colonial traditions was very often broadcast by Moscow through the

1 There are three grammatical genders in the Russian language: masculine, feminine, and neuter.

Words like country, land, Central Asia are feminine.

2 Originally, the sculptures were supposed to be nude in the manner of Greek statues, but the commission demanded that the sculptures be clothed. 
prism of liberating the women of the East, dropping old shackles, including burqa, as well as the tyranny of men, with its early marriages, polygamy, etc. Therefore, the Soviet Union's struggle for Central Asia was kind of a gender struggle in which two masculine actors fight each other for women.

In this triad, one of the masculine (native) actors turned out to be superfluous, since from a formal point of view he was the bearer of outdated patriarchal traditions. The new masculine actor, who came from outside, acts as a representative of power. In this scheme, the Other is constantly semantically ambivalent: they are both masculine and feminine, as well as semantically dualistic, some are aggressors and others are victims.

The interest of the country's top leaders (Stalin, Brezhnev) in the American Western eventually led to the birth of a quasi-western in the USSR. This genre may subsequently be called Eastern, which to some extent emphasizes both the regional and the national specificity of these films. To some extent, it can be argued that the appearance of Eastern had both subjective and objective prerequisites. On the one hand, it was a response to the order of the highest party leaders to create action-style films, on the other hand, these films filled a niche in the country's colonial history, showed the greatness of the USSR in the development of new territories and assistance to local peoples. At the same time, it is quite surprising that the Eastern, as a kind of analogue of the heroic Western, was not widely used in Soviet cinema, despite the popularity among the Soviet audience, and even some support from the leaders of the USSR ${ }^{1}$.

True popularity Eastern received only in 60-70s with L.I. Brezhnev as the ruler of the USSR. The "White Sun of the Desert" has become peak of this genre. I am trying to show that in this film, as in a mirror, the whole complex history of Soviet cinematography was reflected with its genre peculiarity. Practically both structurally and semantically, this film is one of the best and most typical orientalist films.

The Other's physicality is written out in this film in such typical images that it could be the best illustrative material of Cultural Encounter. The movie begins with a journey of the main hero - a Red Army soldier comrade (tovarishch') Sukhov ${ }^{2}$ walking home through the desert near the east shore of the Caspian Sea. For several years he fought in Central Asia with the enemies of Soviet Republic and now he may return home to Central Russia to his beloved wife who comes to him in dreams. The

1 One of the first Easterns, shot in response to Stalin's request, was The Thirteen (1936), an imitation of John Ford's "The Lost Patrol" (1934).

2 Fyodor Sukhov was played by a well-known actor Anatoly Kuznetsov (1930-2014). 


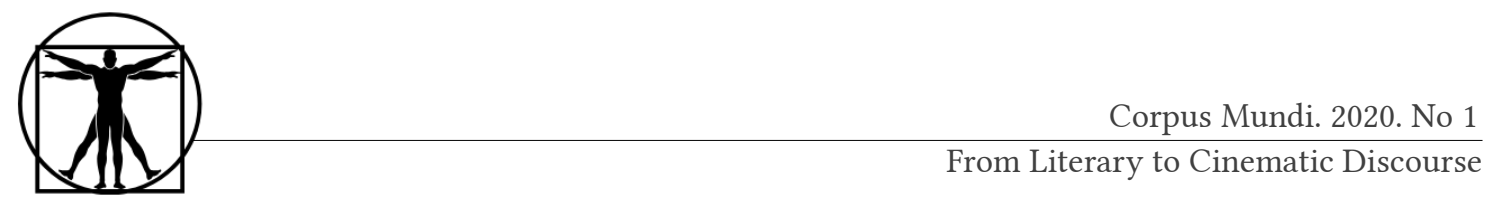

green landscape of his dream against which he sees his wife is a full contrast to the emptiness of the desert. So the hero moves from the emptiness of the desert (dystopia) to the bucolic (utopic) landscape of his homeland. At the same time the dystopia is real and the utopic landscapes he sees only in dreams.

This given opposition of landscapes will be constantly supplemented throughout the film. The entire film is built on simple oppositions, and binary structures dominate throughout the film, almost from the first shots. But it does not mean that the film is simple. No, on the contrary, it is very complicated, with many innovative ideas ${ }^{1}$.

The meeting with the Other's body begins immediately, almost with the very first shots, this meeting resonates with the images from Sukhov's dream when he sees his native land and his beloved woman. This meeting with the Other violates the "emptiness" of the landscape, but in reality, it is not just a meeting with the Other - Sukhov sees only a head, since the whole body of the Other is buried in the sand. This puts the hero in a special position of "the relationship with the Other, the face-to-face with the Other, the encounter with a face that at once gives and conceals the Other, is the situation in which an event happens to a subject who does not assume it, who is utterly unable in its regard, but where nonetheless in a certain way it is in front of the subject. The other 'assumed' is the Other" (Levinas, pp. 78-79).

The complexity of this situation is that such a meeting, as Sukhov explains, is already the third one. And he does not know what awaits him, since the essence of the Other is indefinite. He is hidden from the subject, incomprehensible to him ${ }^{2}$. Let's return back to Said buried to the neck in sand. We see a person deprived of a body, that is, of an integrity - a magnificent episode in terms of symbolism and meaning, because it is Sukhov who will have to restore wholeness of this person. This "face" is practically devoid of emotions, it is speechless, which is also very symbolic. But Sukhov will have to restore the integrity of this person, to return his full form, since the subject is in a borderline state between life and death. Sukhov watered him and dug him out of the sand, thereby appropriating him somehow ${ }^{3}$.

1 Unfortunately, because of the format of this article, we cannot focus on these points, though they are worth to speak about.

2 In one case, the saved man tries to kill Sukhov after he was dug up.

3 Grateful Said would come to his help again and again throughout the film. 


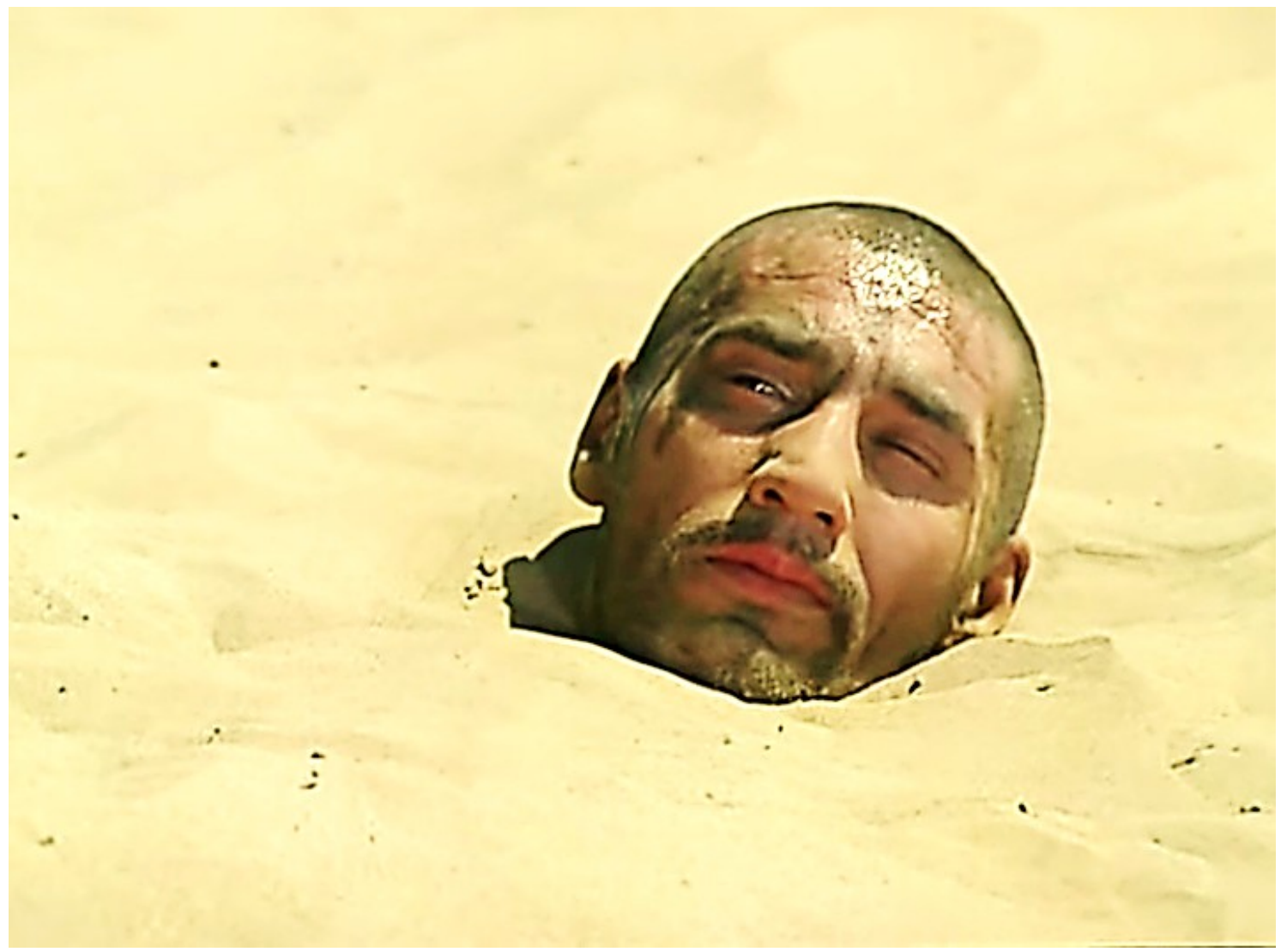

Fig. 1. A frame from the film "The White Sun of the Desert". The head of one of the characters (Said) of the film, buried around the neck in the sand

Thus, this face of the Other, or rather his incomplete image, turns out to be a peculiar leitmotif of the film. The characters of the film are constantly involved in the knowledge and awareness of the Face of the Other.

The central theme of an Eastern is the struggle of various masculine agents for women. The antagonist of the Red Army Soldiers in the film is a bandit named Abdullah, who before running abroad, decides to kill his own wives so that they don't fall into the hands of the "uncircumcised", as Abdullah himself explains. All this adds to the film an additional "phallocratic aesthetic", as defined by Kenyan scholar G. Musila, who uses the term "in reference to the ways in which certain hegemonic masculinities have historically been mobilized in constructions of state power and leadership" (Musila, p. 151). But Abdullah failed to kill all his wives, as the Red Army detachment arrived in time to save them from death. The transition of women to the protection of Soviet power creates a new conflict and further enhances the "phallocratic" aspect of the film. 

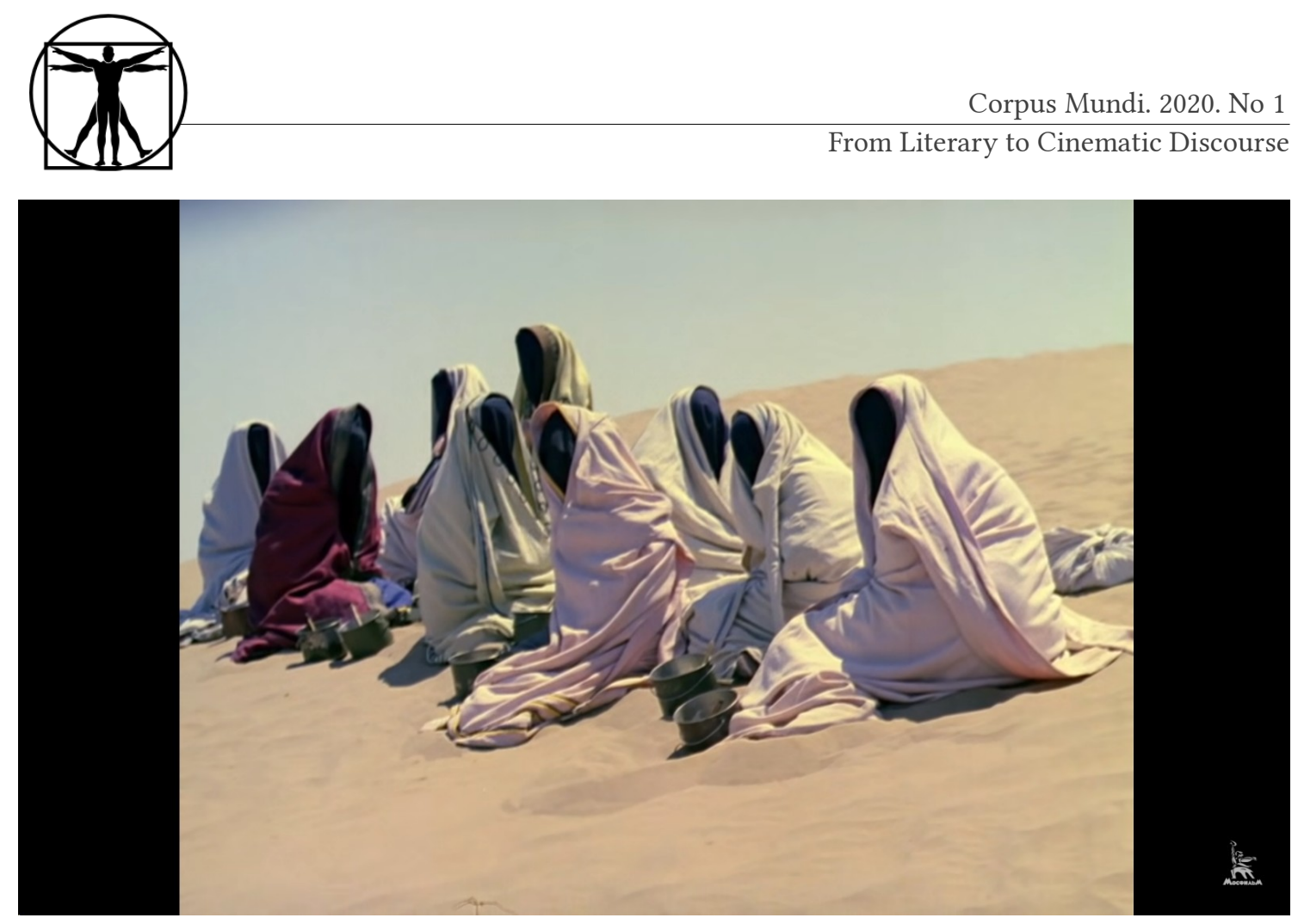

Fig. 2.

\section{THE EAST WITH NO FACE. THE ABDULLAH HAREM UNDER SUKHOV PROTECTION}

Women in the film are only an addition, an attendant circumstance; they are deprived of their self. Although each of them has a name, but there is no personality detectable, since their faces are almost always hidden under the burqa. Actually, the burqa in this film has a dual function: it seems to indicate that the events of the film take place in Central Asia ${ }^{1}$, and that the woman there is deprived of freedom and reduced to the level of a thing. So that we do not doubt such an interpretation, in one of the episodes the camera grabs a red propaganda poster that says: "Woman is also a Human". Although the filmmakers themselves do not fully believe in this, since Abdullah's wives in the film are no more than an annoying misunderstanding. They prevent Abdullah from fleeing abroad, they make Red Army detachment chase Abdullah through the desert, and they prevent Sukhov, whom the commander of the Red Army detachment asked to escort the women, from going back home.

1 The burqa in this film is just a primitive tribute to the stamps - the Oriental woman had to have a closed face. In reality, the Turkmen women did not cover their faces. The nomadic peoples of Turkmenistan, Kazakhstan and Kyrgyzstan were not great adherents of Islam, which is understandable because of their nomadic lifestyle. 
The only one who is fully interested in "revealing their face" is a young soldier Petrukha who dreams passionately of seeing the face of Gülchatai, the youngest ex-wife of the bandit - her appearance is hidden under a burqa. This facelessness of an oriental woman attracts a Russian guy, makes him fall in love with the impersonal image of an oriental beauty.

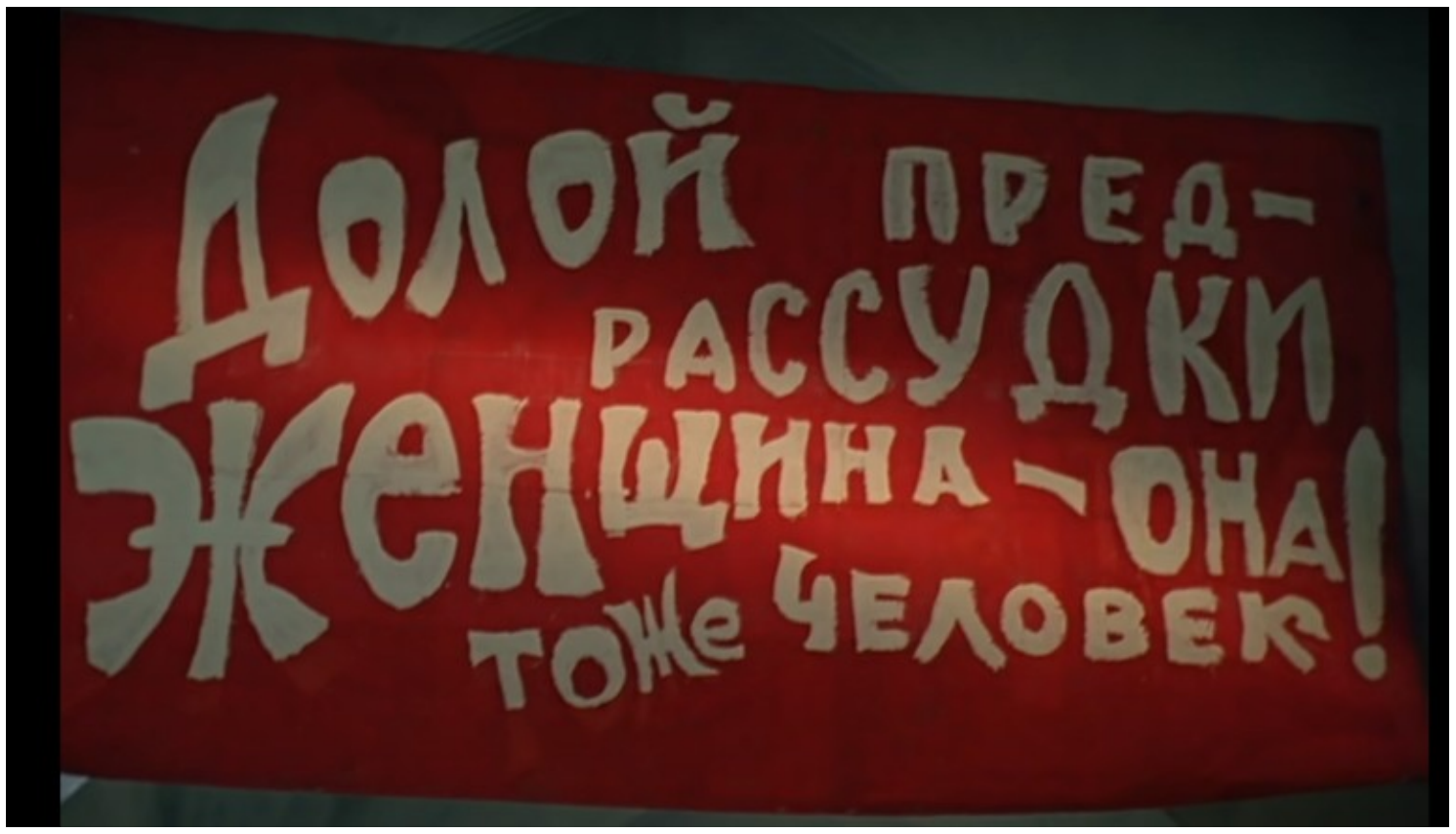

Fig. 3. The Revolutionary poster tries to persuade us:

"Get rid of prejudices. A woman - she's also a human being".

"The White Sun of the Desert" typifies a clash of Civilizations through the prism of a clash of Faces. To see the face of the Other is to know him (her), accept or reject him (her). In the image of Petrukha, we find a passionate, but naive desire to get acquainted with the Face of the East, to love her - it sounded so loud in this film. Unfortunately, this did not happen, because the East in the person of the bandit Abdula (the Past) did not want to accept the West, and the East (the Future) in the face of new carriers of Oriental values could not transform into a new one. Moreover, these representatives of the East of the future are not present in the film. The women meekly accept their fate, believing that they now have a new husband. By the law of the strong, this place should be taken by Comrade Sukhov. 


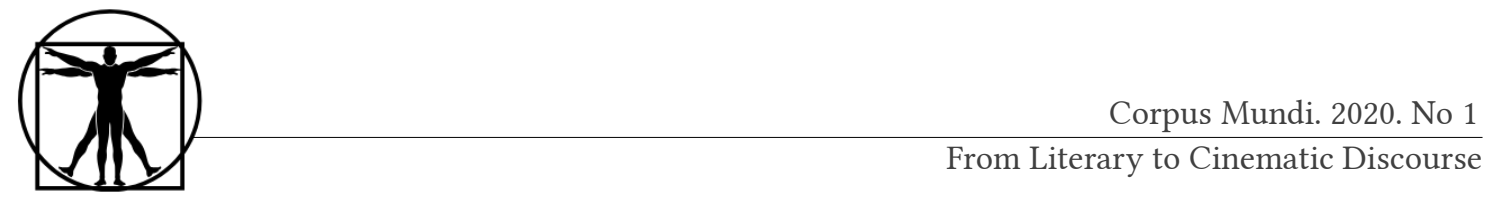

In fact, not only women are just part of an imaginary landscape ${ }^{1}$. These are also the old Turkmen, resignedly sitting under the scorching sun. They do not even bother with the fact that under the head of their dying fellow lies a box with dynamite with a burning wick. Time seemed to stop for them: "We are sitting here for a long time", - one of them explained. This frame is repeated several times in different contexts, in different landscapes. Nothing changes with them; they just sit there silently. They can't even be stirred by an explosion that thundered nearby tearing turbans from their heads. These turbaned locals are just a tribute to the imaginary landscape, since it would be more appropriate for Uzbekistan than for Turkmenistan. These old people appear to be conditionally animated. Thus, most of the characters in the film are parts of an imaginary topos rather than a real locus, although the locus is indicated in the film. They are like part of the scenery, more markers than agents.

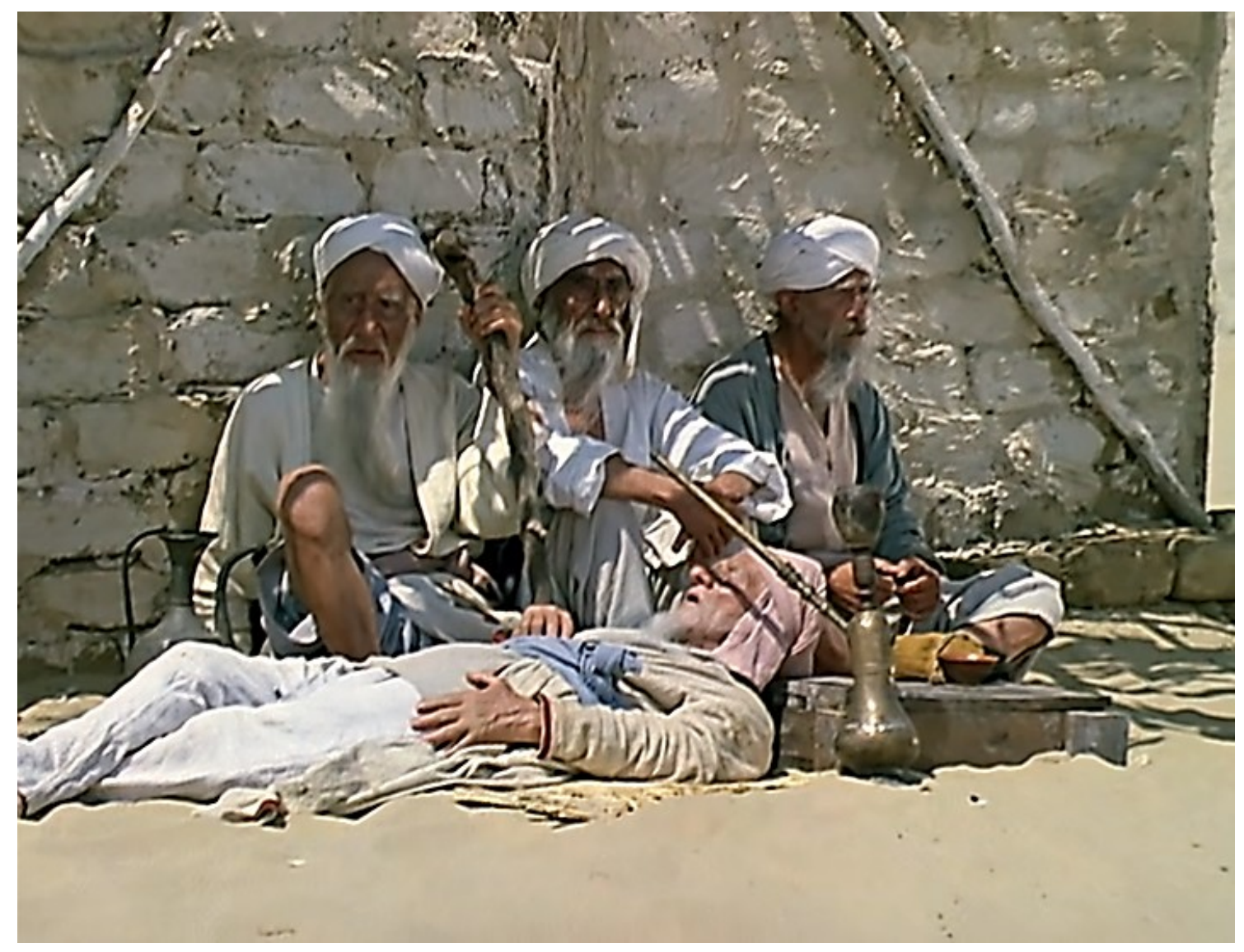

Fig. 4.

1 "Imagined" as their clothes and their behavior are conditional, does not reflect the real characteristics of the region, but is created to please the conditional typicality. 


\section{PEOPLE ARE ONLY A PART OF LANDSCAPE. THEY ARE MOTIONLESS AND SPEECHLESS}

It is noteworthy that the Red Army, with the exception of a few characters, also turn out to be just a scenery. They are not just superfluous; they are faceless tools of the historical process of "liberation of Central Asia". In the script of the film we read: "The Red Army detachment, forty sabers, was rushing through the desert to the Black Fortress oasis. There were 15 Russians, 12 Turkmens, 9 Kyrgyzs, 4 Uzbeks, 6 light machine guns and 18 carbines in the detachment. Everyone had revolvers, and commander Rakhimov had one grenade. The detachment moved without rest, and the horses and people were exhausted to the limit, but they did not slow down their pace" (Ezhov \& Ibragimbekov, pp. 9-10). The characters are depersonalized, reduced to the level of tools, or rather weapons: the authors list in one sentence their ethnicity and, immediately after that, their weapons (6 light machine guns and 18 carbines). One might think that before that some types of weapons were also listed. Only the commander is highlighted. The detachment moves without rest, like some sort of machine, everyone is exhausted, but they do not slow down their pace - the detachment has only a goal that forces it to move stubbornly through the desert.

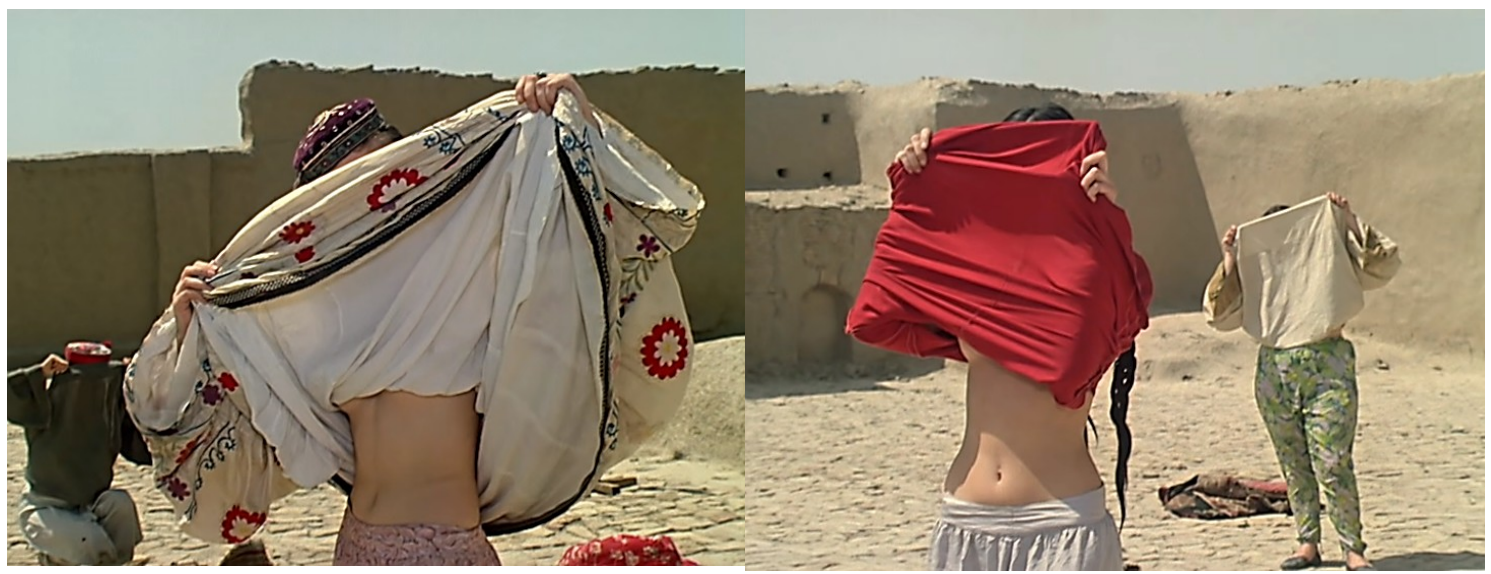

Fig. 5. The Faces are covered. But the filmmakers couldn't avoid the eroticism of the image of the East

Not only does everyone in the film have their own role, better said, their own function. And the function has no personality, it's just a standard set of actions ${ }^{1}$. But even in this reduction of the characters to the level of function - the film is very interesting and unusual, not without reason it was so ambiguously accepted by the state commission. M.

1 That's why we find in the film many functions and few characters. 


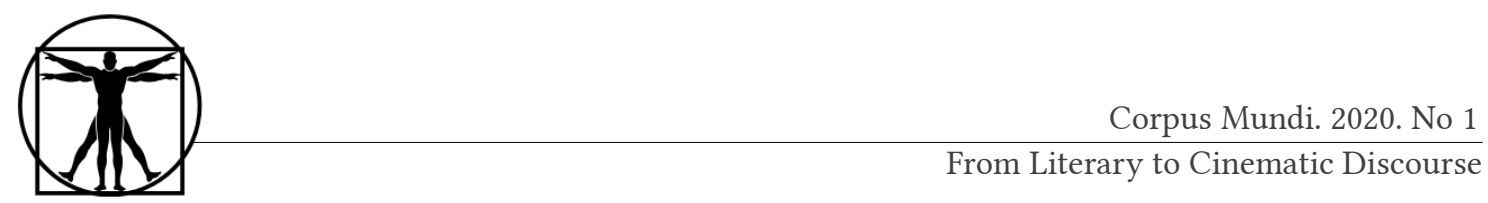

Kachalova, the head editor of "ETO" - film company, where this film was shot, described the first footage as follows: "The material has obvious successes and obvious failures. Luspekaev is very good ${ }^{1}$. Abdullah is very good -- magnificently filmed. Wives are also good. Petrukha is pleasant, texturally pleasant. But Kuznetsov isn't good. The wrong hero, unpleasant, immense" (Razzakov F. , 2005, p. 624).

It seems to us that this characterization misplaced the priorities in the film. The head editor never understood the significance of this film, the symbolic load of its characters. In many ways, this film has overtaken its time, and to a large extent, as one of the archetypical films dedicated to the civil war in Central Asia, it nevertheless broke all stereotypes.

Why was Sukhov taken so cold by the commission. The answer is simple. For the same reason that he was so well received by the audience. Sukhov had "face", had personality. And this individuality was not in accordance with the function. He was not a typical Soviet cinematographic character ${ }^{2}$. There was a lack of ideology in his actions. Only once we hear a long speech where he explains to the women their bright future. His inner intentions are not in concordance with the revolutionary ideas.

Sukhov, being an antagonist of Abdullah, does not claim his harem to himself, although Abdullah's wives acknowledge him as their new husband. It is from them that an erotic message comes; they wait for his love and indignantly condemn Gülchatai for not caressing their new husband well. He is maximally masculine, brave and experienced in battles $^{3}$. At the same time, Comrade Sukhov is also the Other, only his otherness results not out of his connection with the landscape, out of his function in the film - he is a wanderer who comes to the aid of all who need it. He himself is in a borderline state between worlds or civilizations; he is stuck in this space of uncertainty. That is why he is constantly forced to stray, return, perform feats or good deeds. He leaves and comes back again.

1 Pavel Luspekayev's role in the film was a head of Russian customary on the Caspian shore - Pavel Vereschagin. Although Luspekaev had a minor character role, many critics thought that he had become one of the Central figures of the film. In addition, his character broke all the stereotypes of Soviet cinema. Being the chief of the Tsarist customs and a Tsarist officer, he would automatically have to be in the enemy's camp. But he takes a neutral position, because for him it is more important to serve the Fatherland, and not some ideological principles. In the end, he goes to the side of Sukhov, and dies, having fulfilled his duty.

2 The Commission always carefully made sure that the positive character was neatly dressed, spoke correctly, and his actions should be an example to follow

3 One of the most important episodes of the testing of Sukhov's masculinity is the moment when Vereshchagin throws him a lit up checker of dynamite at a request for a lighter. He quietly watches as the match cord burns down, lights the cigarette, and only then throws out this checker, which explodes in the air. 
Almost all the main characters get stuck in this space for a while: Sukhov, Vereshchagin, and even Abdullah. Everyone has some kind of obligations, unfinished business, moral principles that determine their actions. There is almost no ideology in the film, or this ideology is blurry, unmanifest. There is no implacable class struggle. Since even the main antagonist of the film - Abdullah - is not a class enemy. In the past, he was just a poor man, like Said. Their fathers were even friends. He is an enemy, but a respected adversary, brave, skilful and merciless. Perhaps he is the only truly masculine character in the film ${ }^{1}$.

Abdullah's masculinity is also determined by his role as a husband he is the only one who claims his rights to women and their fate. He is the personification of the "phallocratic aesthetic", which is clear in the scene where he murders Petrukha, who was so eager to see Gülchatai's face. Abdullah not only kills his wife Gülchatai, but, putting on her clothes, he kills Petrukha, who mistook Abdullah for the beloved woman. He makes that «in a shocking demonstration of the 'father's' phallic power. Abdullah grabs Petrukha's rifle and thrusts the bayonet into the young man's heart». (Prokhorova, p. 64).

We agree with Prokhorova's definition of this murder, but not with relating it to the right of paternity. Abdullah is no father ${ }^{2}$, there is courage in his image, militancy, but not fatherhood. Even his correlation with the status of a husband is very conditional; he easily abandons his wives. And in all his actions to return them he shows not the desire to save his wives, but the desire to not allow other males to own them.

In fact, Abdullah is also a marginal person, dreaming of going beyond the limits of his place in this story. He can hardly be called cruel; he is just a person who does not stop at anything. For him, there are no moral principles, there is only the desire to command and survive at all costs. But with all his incredible vitality, he is also doomed to destruction.

In general, the "phallocratic aesthetic" is also associated with Vereshchagin. True, here this aesthetics is very complex, the boundaries of hypermasculinity are outlined as much as possible; this aesthetics is eroded by a host of other symbols. On the one hand, Vereshchagin is

1 A Georgian actor was casted for this part, as the filmmakers found the type to be more important than reality (ethnicity). The viewers didn't know about this substitution, for to them the image was also more important than the anthropological type.

2 Is not a father/child conflict. This is a conflict between a patriarchal husband and an infantile fiancé. It's quite symbolic that Abdullah kills his rival with Petruha's own weapon. In reality, the filmmakers from the very beginning prepare us for this scene -- in the beginning of the film Sukhov takes Petrukha's rifle, but it malfunctioned, it is not able to shoot, although in the end produces a shot at the most inappropriate moment. This infantile phallic helplessness, symbolically reflected in his weapon, which does not fire, cannot compete with Abdullah's phalocratic aesthetic, who launches his mauser at every opportunity. The defeated young guy, the failed groom, from whose body a rifle with a bayonet protrudes, is a rather symbolic frame of celebration of this aesthetic 
maximally "phallocratic". He is, except for Commander Rakhimov, the only representative of the government, everyone respects and reckons with him. Even Abdullah is ready to pay him for his smuggling, although from a formal point of view he no longer keeps a customs post. Vereshchagin is an old soldier, a war hero; he was twice awarded with the Order of St. George. In his house, he keeps an arsenal of the most diverse weapons: machine guns, grenades, dynamite, and cartridges. He is brave and sometimes even reckless. But he is also kind, sympathetic, and obedient to his wife, who keeps him locked so that he does not get involved in any heroic story. His house is a real oasis in the desert -a vineyard, peacocks, a pool with sturgeons.... To one degree or another, his house is a kind of dwelling of some emir or khan in miniature.

But at any moment, he can turn into an infantile child, whimpering because he has to eat caviar without bread, and his wife feeds him from a spoon. And here we see unfinished masculinity, his masculinity is in a state of trauma (by the death of his son, loss of his rank, crisis in the country $^{1}$ ). His masculinity is conditional, it is only part of his heroic past, which is not compatible with his character. In the end, his wife completely deprives him phallocratic qualities, throwing in a sea all his rich armory, and he can only passively watch it. Symbolically she castrated him, taking away all those weapons that construed his nature. Only the news about the death of Petrukha whom he accepted as a son, makes him return to his real phallocratic nature that leads him to his death.

But it is death that returns to him his lost masculinity, since «death becomes the limit of the subject's virility, the virility made possible by the hypostasis at the heart of anonymous being, and manifest in the phenomenon of the present, in the light» (Levinas, 1987, p. 74).

All this turns out to be a peculiar paradox of the plot, because only Sukhov and Said remain alive, unless, of course, we take into account the surviving wives of Abdullah and the detachment of the Red Army under the command of Rakhimov'. Vereshchagin's wife Nastasya is heartbroken. Her life is completely ruined.

In this extravaganza, in this the cycle of passions, lives, old and new colonial stories, only one character among the Others remains integral Said. This character was played by the famous Soviet (Russian) actor Spartak Mishulin, who could not pretend (anthropologically) to play the role of a Turkman, but perfectly coped with this role. Said is integral and

\footnotetext{
His phrase - "I feel ashamed for the State" - shows that clearly.

2 Rakhimov is not the character of the second, but of the third plan. He always goes somewhere (it is clear that he is chasing Abdullah, who is always in another place), and every time Rakhimov appears at the very last moment, when everything has already happened.
} 
consistent. The film begins with the main character meeting him and ends with their departure. He is laconic, as are the majority of Turkmen characters. Said is a man of duty and honour. That is why he is forced to return constantly, since he owes two debts: one to his dead father, and the other to Sukhov. He seeks revenge for the murder of his father, and at the same time he has to respond to every shot, believing that Sukhov needs his help. In his dressing gown torn by bullets in several places, he is a magnificent type of frontier character stuck between two worlds. And it's hard to say which world he is more devoted to, because he constantly makes choices in one direction or another.

There is masculinity here (courage, dexterity, ability to fight, devotion, etc.), but this masculinity is abstract, incomplete, devoid of many important components - no home, no family, only the filial duty to avenge the death of his father. Often, he simply observes from the outside, intervening in the process only when the situation threatens the safety of Sukhov.

Of course, the marginality of all these characters is not that special, because they belong to a kind of frontier heterotopy, for which marginality is natural. At the same time, this marginality is external, forced, imposed on them from outside. They all strive for a certain homogeneity, the completeness of the understatement in which they find themselves. Perhaps it is because of this marginalization that these characters are so loved by all Russian people; even Soviet and Russian cosmonauts liked to watch this film before flying to Space. After all, each of them to some extent imaged himself to be like a comrade Sukhov facing the unknown. They felt a certain affinity to Sukhov in this frontier uncertainty.

But looking back at the image of the Other and his (her) fate, we note that only Abdullah 's harem acquires completeness.. In the last frames of the film, we see them taking off the burqa, having a peaceful dinner at the fire. They no longer hide their faces, there is no tension in their poses.

But among them there is no Gülchatai, and nearby there is no Petrukha who wanted so much to see the face of his beloved one.

Unfortunately, no dialogue took place. This meeting of cultures proved fatal to many of its participants. And the one who survived is now striving to leave the place of this dialogue.

"The White Sun of the Desert" is an attempt to understand the Other by looking at him. A copy and an approximation of the Western turned into a Soviet or more precisely Russian "Eastern", this Russian cultural paradox absorbed the opposite trends: there we find colonial nostalgia 


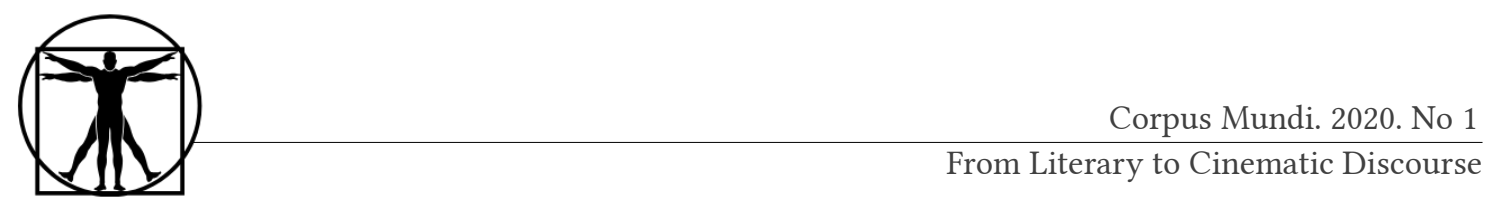

and post-colonial reflexion, because there is no negative Other. All the characters (both Selves and Strangers) are beautiful in their own way.

Moreover, "Persons of Asian Nationality", depicted in the film, are dearly loved by the Soviet audience. The fact that many phrases pronounced by Said and Abdullah (Kakhi Kavsadze) have become idiomatic is a proof of this popularity. And the wives from Abdulla's harem were "honoured" by giving their names to the craters of Venus "there are the small craters of Zarin, Jamilya, Güzel, Saida, Khafiza, Zukhra, Leila, Zulfia and, of course, Gülchatai. 'Dear Katerina Matveevna' is not forgotten either - there is crater Katia here too" (Burba, 2005).

And yet, "The White Sun of the Desert" - a typical western with a lonely hero, designed to save the local population from bandits, however, to some extent it could be called an antihero ${ }^{1}$ (do not be confused with the villain). $\mathrm{He}$ is always unremarkable, unobtrusive in appearance, but integral internally. Sukhov is a Soviet analogue of Clint Eastwood in his famous "Dollar Trilogy", shot by the famous Italian director Sergio Leone. It was these qualities in comrade Sukhov, performed by the wonderful film actor Anatoly Kuznetsov, that so much irritated the censure committee. We would call him "a faceless man", colorless character against the background of the Faces of the Other. For the same reason, C. Eastwood 's character is called 'Man with No Name'.

This moment was noted by Prokhorova, who quoted a song from the film "Officers" in her article on the cinematography of the Brezhnev era: "Of the heroes of the past / Sometimes not even names are left. / Those who engaged in deadly combat / Became earth and grass" (Prokhorova, $p$. $60)$.

It is precisely these qualities that turn him into a certain a 'superhuman' (here again the analogies with F. Nietzsche are being asked for), an inconspicuous sage (Zarathustra) returning home, carrying the truth, or rather freedom, to people. And in this ideological paradigm, the film loses its post-colonial focus, turning into its opposite, which is not surprising, because the filmmakers shot what was originally meant as a Western. In this mixture of styles and images a new metaphor of the Other was created; however, it did not last long, giving way to a new

1 That is why the heads of the studio reacted so negatively to the image of Sukhov. He did not fit the standard of "hero". According to unwritten laws of Soviet cinematography the hero had to be perfect (clean shaved, neatly dressed), but Sukhov visually violated all the canons. And his behavior was also controversial. Only once he sank down to propaganda of communist ideals. More often his behaviour was ambiguous. He leaves the harem with Petrukha in the fortress and goes to the sea to swim and then to continue his way home. At this moment the bandits attack inexperienced Petrukha and capture the harem. His actions are often reckless, incomplete, and lead to the opposite result. But he is a strong, willful, skillful person. 
Other or Alien, with which dialogue is possible only from the position of power.

But the post-colonial sentiment on the "White Sun of the Desert" type of the Other has not completely disappeared, it has repeatedly manifested itself in various attempts to chart a dialogue with the Other, a good example of which being the film "Muslim" (1995), in which the Other was depicted with a 'Russian face', but 'Alien mentality'. This Russian person of "Afghan nationality" demonstrated as best as possible all the problems of the Afghan syndrome and broke stereotypes in the image of the Other generated by the Afghan problem. Rather, it resembled the so-called revisionist Western, which appeared in the United States in the 1970-1980s in the wake of a review of American colonial policy.

Unfortunately, the post-colonial perspective of the Other in such Russian films was rather an exception, as the society, traumatized by the collapse of the USSR and the separation of the union republics, did not want to tolerate the notorious concept of a new historical community the Soviet people - any longer. The public consciousness was also alien to the post-colonial rhetoric of the Other. The post-Soviet space was dominated by the slogan: The one who is not with us is against us! The dialogue of cultures failed. Traditional public consciousness painted the terrible Face of the Other. Of course, this disease was not typical only of Russian society. To varying degrees, many post-Soviet republics have been or still are sick with it. "Thank you, God, that I am not moskal!" Ukrainian youth still exclaims, while the Russians echo this battle cry with equally vicious attacks.

\section{THE CUMAN DANCES. EPILOGUE}

When the article was ready for publishing, political events in Russia took an unexpected turn, forcing us to return to the article, re-read it, and even add some material, which we previously considered unnecessary and not directly related to this film. But on Wednesday evening, April 8, 2020, the president spoke to the Russians ${ }^{1}$ about the coronavirus situation in the country, and in the conclusion of his speech he summed up: "Dear friends! Everything goes by, and this will go by too. Our country has been through serious tests more than once: the Pechenegs and the Polovets tormented it - but Russia has handled everything. We will win this coronavirus infection. Together we will overcome everything" (Putin, 2020).

1 More precisely, he spoke to the heads of regions, but all Russians could hear this speech. 


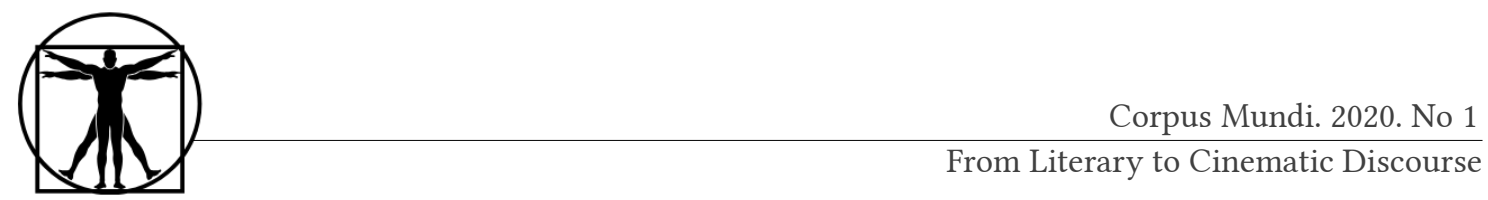

The President's phrase, that metaphorically connect the difficult situation in the country with the invasion of the Polovets (more known in the West as the Cumans) and the Pechenegs, illustrates our article perfectly. The meeting with Others on the borders still lives in the minds of many Russians and takes quite concrete forms.

The external threat in the President 's speech was not related to the Swedish, Teutonic knights ${ }^{1}$, and even Mongols. There was no mention of the Nazi troops, which are usually called and conceptualized as the Horde. Instead the nomads of the Great Steppe suddenly sprang up to the President's mind.

Russia, so to say, is sick with the Other; and in this desire to create a stereotype of the Other or Alien, modern Russian public discourse is similar to the medieval Russian chronicles and the folk tradition describing the mythological character 'Bonyak the Mangy', whose prototype was a Cuman Khan of the XI century. Some legends about him existed up to the end of the 19th century. In these chronicles and bylinas ${ }^{2}$, Bonyak (Bonyaka, Bunyak) appears before us as a terrible monster - a dwarf with grotesquely big insides (liver and lungs), which hang as far as versta (1066 metres) behind his body (Zhdanov, pp. 442-460). In other stories, he is depicted with a huge head (Zhdanov, p. 46) and huge eyelids hanging above his eyes, not unlike the monster Vyi in a novel by the great Russian writer Gogol (Levkievskaja, p. 310). When his head was cut off, it rolled over the steppe for a long time and killed everything on its way (Pletnyeva, p. 46). This awful face "of the Cuman nationality" has long been scaring the Russian, Ukrainian, and Polish people who attributed various properties to this mythological character.

This semantic dismemberment of Bonyak, which reduces him to the head or even to an exaggerated face (eye) results in creating of the Other, someone who potentially poses a threat. The fact that Bonyaka Khan was not an enemy of the Russians, but often their ally, the folklore discourse left without attention. He was beyond understanding, beyond traditional cultural patterns, and it made him dangerous and terrible. The eyes of a horrified person are big, and equally 'big' are the eyes of the being instilling that horror. Therefore, the body deforms or disappears at all, and a huge head or eyes that left alone cause horror.

1 Battle with the Swedes is one of central themes of Russian discourse and exists in two variants: the Battle of the Neva (1240) and the Battle of Poltava (1709), the later - a crucial point of the Great Northern War. The mention of the battle of Poltava gave birth to a Russian idiom - 'like the Swedes near Poltava' in the meaning of 'total defeat' or 'complete loss'. Knights of Teutonic Order are also seen as one of the main invaders and enemies of Russian State in the Middle Ages.

2 Bylinas - old Russian epic poems. 
Oddly enough, by using the expression "a face of Caucasian nationality", (the literal form of the Russian expression for "a Caucasian ethnic") we act on the same principle, engaging in verbal vivisection, reducing the Other to the face, hypertrophying the face as the basis of the ethnic metonymy.

This mental construction suggests no dialogue, this process is singlesided. Needless to say, the object also needs unilateral construction, and so regularly acts as a subject of similar operation. There is no dialogue, there is only a passion for the fruit of one's own imagination. When the Red Army soldier Petrukha tried to comprehend the subtleties of the East, he longed for the knowledge of the Other, passionately wanted to look in their face. But whether it is because of his naiveté, or by tragic accident he was never granted this opportunity.

Comrade Sukhov himself knew everything about the East, but his heart was in Russia. He sought her, dreamed of her. He is a lonely person; his task is to perform feats, but not to learn the East. The finale is very sad: Petrukha is killed, Abdulah is killed, Gülchatai is killed. Therefore, Gülchatai's face remained unidentified.

We are challenged not only to see the true face of Gülchatai, but also to learn to speak to her. Impersonal heroes or wonders with hypertrophic faces generated by our fears should not haunt us. It is necessary to help our vis-à-vis to see our real faces, not the ones invented by them or us. Face-to-face meeting should take place not in the form of a subjective monologue of national fantasies, but in a constructive dialogue in which everyone seeks to understand the Other.

\section{References}

Abul-Kasymov, K., Ginsburg, S., Dolinskiy, I., Zhurov, G., \& Zak, M. (Eds.). (1969). The history of the Soviet cinema. Moscow: Iskusstvo. (in Russian)

Anderson, B. (2006). Imagined Communities: Reflections on the Origin and Spread of Nationalism. London: Verso.

Bairieva, A. (2016). Turkmen national costume (late 19th - early 21st century. In N. A. Dubova (Ed.), Turkmens (pp. 239-264). Moscow: Nauka. (in Russian)

Bonnell, V. E. (1993). The Peasant Woman in Stalinist Political Art of the 1930s. The American Historical Review, 98(1), 55-82.

Burba, G. (2005, 12 15). Outerspaces Menologium. Retrieved from Galspace: http://galspace.spb.ru/nature.file/02 010.html (in Russian)

Bustanov, A. K. (2014). Soviet Orientalism and the creation of Central Asian Nations. London and New York: Routledge. 
Derrida, J. (1985). The Ear of the Other: Otobiography, Transference, Translation. New York: Schocken Books.

Ezhov, V., \& Ibragimbekov, R. (1971). The white sun of the Desert. Moscow: Iskusstvo. (in Russian)

Fabian , J. (1983). Time and the other: how anthropology makes its objects. New York: Columbia University Press.

Graham, S. (2016). Soviet Film Comedy of the 1950s and 1960s: Innovation and Restoration. In B. Beumers (Ed.), A Companion to Russian Cinema (pp. 158-176). Malden, MA: Wiley Blackwell.

Jersild, A. (2003). Orientalism and Empire: North Caucasus Mountain Peoples and the Georgian Frontier, 1845-1917. Montreal, London: McGill-Queen's University Press.

Johns, A. (2004). Baba Yaga: The Ambiguous Mother and Witch of the Russian Folktale. New York: Peter Lang.

Khrennikov, T. (1960). Selected Songs (Vol. 1). Moscow: Sovetskiy Compozitor. (in Russian)

Levinas, E. (1987). Time and the Other. Pittsburgh: Duquesne University Press.

Levkievskaja, E. E. (1998). On the Question of Mystification of Gogol's Vij in Light of Ukrainian Mythology. Studia Mythologica Slavica, 307-316.

Maryamov, G. B. (1992). Kremlin censor: Stalin is watching a cinema. Moscow: Kinotsentr. (in Russian)

Musila, G. A. (2012). Violent masculinities and the phallocratic aesthetics of power in Kenya. In S. Opondo, \& M. J. Shapiro (Eds.), The New Violent Cartography: geoanalysis after the aesthetic turn (pp. 151-170). New York: Routledge.

Nietzsche, F. (2006). Thus Spoke Zarathustra. (A. Del Caro, R. Pippin, Eds., \& A. Del Caro, Trans.) Cambridge, New York: Cambridge University Press.

Pletnyeva, S. A. (1990). The Cumans. Moscow: Nauka. (in Russian)

Prokhorova, E. (2010). Mending the Rupture: The War Trope and the Return of the Imperial Father in 1970s Cinema. In H. Goscilo, \& Y. Hashamova (Eds.), Cinepaternity: fathers and sons in Soviet and post-Soviet film (pp. 51-69). Bloomington, Indianapolis: Indiana University Press.

Prusin, A. V., \& Zeman, S. C. (2003). Taming Russia's Wild East: The Central Asian historical-revolutionary film as Soviet Orientalism. Historical fournal of Film, Radio and Television, 23(3), 259-270.

Putin, V. V. (2020, April 8). The meeting with heads of regions on combating the spread of coronavirus in Russia. Retrieved from Russian President: http://kremlin.ru/events/president/news/63 176 (in Russian)

Rakowska-Harmstone, T. (1983). Islam and nationalism: Central Asia and Kazakhstan under Soviet rule. Central Asian Survey, 2(2), 7-87. 
Razzakov, F. (2004). Our favorite cinema: the mystery becomes clear. Moscow: Algoritm. (in Russian)

Razzakov, F. (2005). The death of Soviet cinema. Intrigues and arguments. Moscow: EKSMO. (in Russian)

Sarkisova, O. (2016). The Adventures of the Kulturfilm in Soviet Russia. In B. Beumers (Ed.), A Companion to Russian Cinema (pp. 92-116). Malden, MA: Wiley Blackwell.

Shapiro, M. J. (2004). Methods and Nations: Cultural Governance and the Indigenous Subject. New York, London: Routledge.

Shapiro, M. J. (2013). The Demise of 'International Relations': American Western Palimpsest. In M. Power, \& A. Crampton (Eds.), Cinema and Popular Geopolitics (pp. 29-50). New York: Routledge.

Shapiro, M. J. (2016). Deforming American Political Thought: Challenging the Feffersonian Legacy. New York, London: Routledge.

Zhdanov, I. N. (1895). The Russian old epic poems. S.-Peterburg: Izdaniye L.F. Panteleeva. (in Russian)

\section{Список литературы}

Anderson, B. (2006). Imagined Communities: Reflections on the Origin and Spread of Nationalism. London: Verso.

Bonnell, V. E. (1993). The Peasant Woman in Stalinist Political Art of the 1930s. The American Historical Review, 98(1), 55-82.

Bustanov, A. K. (2014). Soviet Orientalism and the creation of Central Asian Nations. London and New York: Routledge.

Derrida, J. (1985). The Ear of the Other: Otobiography, Transference, Translation. New York: Schocken Books.

Fabian , J. (1983). Time and the other: how anthropology makes its objects. New York: Columbia University Press.

Graham, S. (2016). Soviet Film Comedy of the 1950s and 1960s: Innovation and Restoration. In B. Beumers (Ed.), A Companion to Russian Cinema (pp. 158-176). Malden, MA: Wiley Blackwell.

Jersild, A. (2003). Orientalism and Empire: North Caucasus Mountain Peoples and the Georgian Frontier, 1845-1917. Montreal, London: McGill-Queen's University Press.

Johns, A. (2004). Baba Yaga: The Ambiguous Mother and Witch of the Russian Folktale. New York: Peter Lang.

Levinas, E. (1987). Time and the Other. Pittsburgh: Duquesne University Press.

Levkievskaja, E. E. (1998). On the Question of Mystification of Gogol's Vij in Light of Ukrainian Mythology. Studia Mythologica Slavica, 307-316.

Musila, G. A. (2012). Violent masculinities and the phallocratic aesthetics of power in Kenya. In S. Opondo, \& M. J. Shapiro (Eds.), The New Violent Cartography: geoanalysis after the aesthetic turn (pp. 151-170). New York: Routledge. 


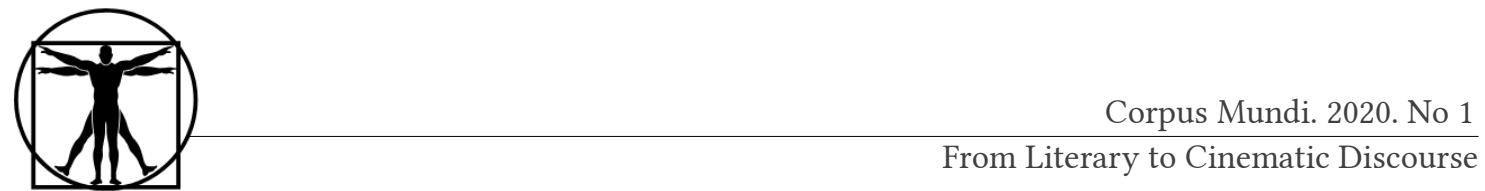

Nietzsche, F. (2006). Thus Spoke Zarathustra. (A. Del Caro, R. Pippin, Eds., \& A. Del Caro, Trans.) Cambridge, New York: Cambridge University Press.

Prokhorova, E. (2010). Mending the Rupture: The War Trope and the Return of the Imperial Father in 1970s Cinema. In H. Goscilo, \& Y. Hashamova (Eds.), Cinepaternity: fathers and sons in Soviet and post-Soviet film (pp. 51-69). Bloomington, Indianapolis: Indiana University Press.

Prusin, A. V., \& Zeman, S. C. (2003). Taming Russia's Wild East: The Central Asian historical-revolutionary film as Soviet Orientalism. Historical fournal of Film, Radio and Television, 23(3), 259-270.

Rakowska-Harmstone, T. (1983). Islam and nationalism: Central Asia and Kazakhstan under Soviet rule. Central Asian Survey, 2(2), 7-87.

Sarkisova, O. (2016). The Adventures of the Kulturfilm in Soviet Russia. In B. Beumers (Ed.), A Companion to Russian Cinema (pp. 92-116). Malden, MA: Wiley Blackwell.

Shapiro, M. J. (2004). Methods and Nations: Cultural Governance and the Indigenous Subject. New York, London: Routledge.

Shapiro, M. J. (2013). The Demise of 'International Relations': American Western Palimpsest. In M. Power, \& A. Crampton (Eds.), Cinema and Popular Geopolitics (pp. 29-50). New York: Routledge.

Shapiro, M. J. (2016). Deforming American Political Thought: Challenging the Feffersonian Legacy. New York, London: Routledge.

Абул-Касимов, К., Гинсбург, С., Долинский, И., Журов, Г., \& Зак, М. (Ред.). (1969). История советского кино. М.: Искусство.

Байриева, А. (2016). Национальный костюм туркмен (конец XIX - начало XXI века). В Н. А. Дубова (Ред.), Туркмены (сс. 239-264). М.: Наука.

Бурба, Г. (2005, 12 15). Инопланетные Святцы. Получено 1532020 г., из Galspace: http://galspace.spb.ru/nature.file/02 010.html

Ежов, В., Ибрагимбеков, Б. (1971). Белое солнце пустыни. М.: Искусство.

Жданов, И. Н. (1895). Русский былевой эпос. С.-Пб: Издание Л.Ф. Пантелеева.

Марьямов, Г. Б. (1992). Кремлевский цензор: Сталин смотрит кино. М.: Киноцентр.

Плетнева, С. П. (1990). Половцы. М.: Наука.

Путин, В.В. (2020, 4. 8). Совещзание с главами регионов по борьбе с распространением коронавируса в России. Получено апрель 8, 20 202, из Президент России: http://kremlin.ru/events/president/news/63176

Раззаков, Ф. (2004). Наше любимое кино: Тайное становится явным. М.: Алгоритм.

Раззаков, Ф. Гибель советского кино. Интриги и споры. 1918-1972. Т. 1, М.: ЭКСМО, 2005.

Хренников, Т. (1960). Избранные песни (Т. 1). М.: Советский композитор. 